\title{
Farmers' action space to adopt sustainable practices: a study of arable farming in Saxony
}

\author{
Malin Gütschow ${ }^{1,2} \cdot$ Bartosz Bartkowski $^{1}$ (D) María R. Felipe-Lucia ${ }^{3,4}$
}

Received: 11 March 2021 / Accepted: 2 October 2021 / Published online: 13 October 2021

(c) The Author(s) 2021, corrected publication 2022

\begin{abstract}
The urgency to address climate change, biodiversity loss, and natural resource degradation requires major changes in agricultural practices. Agricultural policy in Germany has so far failed to generate such changes; meanwhile, public demands for new regulations are met by widespread farmers' protests. Against this background, an improved understanding of the factors influencing farmers' uptake of sustainable agricultural practices is necessary. This study introduces the concept of action space to analyze the role of barriers to change which lie beyond farmers' perceived immediate control. We apply this conceptual framework to the case of diversified crop rotations in Saxony (Germany) and combine semi-structured interviews and a survey to identify key barriers to change and their relative weights. We find that farmers feel rather strongly restricted in their action space to implement diversified crop rotations for sustainable agriculture. The most important barriers pertain to the market environment, which severely limits the feasibility of many crops. In addition, limited regulatory predictability as well as regulatory incoherence and limited flexibility restrict farmers in their action space. The role of resource availability within the farm businesses as well as availability and accessibility of knowledge is ambiguous between interview and survey results. The analysis of interactions indicates that multiple barriers form a self-reinforcing system in which farmers perceive to have little leeway to implement sustainable practices. These results emphasize the need to create an enabling market and regulatory environment in which sustainable practices pay off.
\end{abstract}

Keywords Action space $\cdot$ Agriculture $\cdot$ Agri-environmental policy $\cdot$ Behavioral studies $\cdot$ Sustainability

\section{Introduction}

Communicated by Jasper Van Vliet

Bartosz Bartkowski

bartosz.bartkowski@ufz.de

1 Department of Economics, Helmholtz Centre for Environmental Research (UFZ), Permoserstraße 15, 04318 Leipzig, Germany

2 Department of International Consulting, IAK Agrar Consulting GmbH, Bornaer Straße 16, 04288 Leipzig, Germany

3 Department of Ecosystem Services, Helmholtz Centre for Environmental Research (UFZ), Puchstraße 4, 04103 Leipzig, Germany

4 Department of Ecosystem Services, German Centre for Integrative Biodiversity Research (iDiv), Puschstrasse 4, 04103 Leipzig, Germany
The global food system is an important driver of environmental change, including greenhouse gas emissions, terrestrial biodiversity loss, and soil degradation (UNEP 2016). Agriculture alone contributes $78 \%$ of global $\mathrm{N}_{2} \mathrm{O}$ emissions and $39 \%$ of $\mathrm{CH}_{4}$ emissions (IPCC 2019). Furthermore, loss of landscape diversity, natural habitats, and species diversity as well as damages to soil and water ecosystems are attributed to agricultural production (Campbell et al. 2017). In the European Union (EU), the Common Agricultural Policy (CAP) has been shown to be ineffective and inefficient in delivering on its environmental and socioeconomic objectives (Pe'er et al. 2019). While societal and political demands for environmentally friendly agriculture are growing, farmers claim that new environmental regulations, such as the recently amended fertilization ordinance (a national-level implementation of the EU Nitrate Directive), drive their businesses into unprofitability. Against this background, an improved understanding of the factors 
influencing farmers' uptake of sustainable agricultural practices is necessary.

Many studies have investigated the decisions of farmers to implement sustainable practices. For the European context, Bartkowski and Bartke (2018), Brown et al. (2021), and Dessart et al. (2019) provide comprehensive reviews of the multiple external and internal factors that influence farmer decision-making. The research gaps identified in extant literature include increased attention to measure- and contextspecific factors influencing adoption, meso-level factors such as regional food systems and a more differentiated view on institutional barriers (Baur 2020; Brown et al. 2021; Lamine et al. 2019; Moerkerken et al. 2020; Niles et al. 2016). Furthermore, despite important implications for policymaking, few studies have attempted to separate the decision-making factors within the sphere of influence of farmers from those that lie beyond farmers' control. The present study addresses this gap by developing the conceptual framework of farmers' action space and applying it to the case of diversified crop rotations in arable farming in the German federal state of Saxony.

In Germany, the environmental impacts of the agricultural sector (and, more generally, the overall food system) are substantial (Umweltbundesamt, 2020). Despite high levels of compliance with relevant minimum requirements and regulations, the negative environmental impacts of agriculture continue (KLU 2019). In particular, the simplification of crop rotations has been identified as an important contributor to these adverse environmental impacts (KLU 2019; Heißenhuber et al. 2015). Diversified crop rotations are here defined as spatiotemporal diversification with a higher number of species, with the inclusion of legumes, cover crops and/or perennial forage plants. Multiple beneficial effects of such diversification have been demonstrated in the empirical literature, including above- and below-ground biodiversity (Rosa-Schleich et al. 2019) and soil carbon sequestration (European Commission 2018; Wiesmeier et al. 2020; IPCC 2019) as well as reductions in pest pressure (Lin 2011), nitrogen leaching (European Commission 2018), land degradation (Wiesmeier et al. 2020; IPCC 2019), energy and fertilizer demand (European Commission 2018), and yield risk faced by farmers (Lin 2011). In addition, a more diverse local production can reduce externalities linked to importing products (Magrini et al. 2016). However, the potential effects of diversified crop rotations are often counteracted by intensive management practices linked to the additional crops (Alignier et al. 2020; Hass et al. 2018). For farmers, diversified crop rotations can entail short-term opportunity costs and economic trade-offs but also reduced risks and increased yields in the long term (Rosa-Schleich et al. 2019; Wiesmeier et al. 2020). Despite potential ecological and long-term economic benefits, the implementation of diversified crop rotations remains limited in Germany, especially among conventional farmers.

Responding to the need for a better understanding of farmers' uptake of sustainable practices in general, and diversified crop rotations in particular, this study's objective is two-fold, namely, to (1) conceptualize farmers' action space to implement sustainable agricultural practices and to (2) analyze the constraints limiting the action space of arable farmers in Saxony to adopt diversified crop rotations and the interactions between the identified constraints.

\section{Conceptual framework}

In the following, we first introduce the conceptual framework of the action space, embedding it in the existing literature on farmers' behavior. Next, we describe in more detail the individual barriers that constrain farmers' action space.

\section{Conceptualizing the action space}

Based on a wide range of empirical and theoretical literature, we developed the conceptual framework of farmers' action space, which, in the context of this study, refers to the perceived leeway for implementing (and sustaining) changes in agricultural practices that a farmer has at a particular point in time, given multiple constraining factors (barriers or constraints) that lie beyond the immediate control of the farmer. This definition highlights the conceptual importance of barriers that constrain actors' (here: farmers') ability to do what they (or others) think is necessary or desirable.

The action space is conceptually close to the construct of Perceived Behavioral Control in the Theory of Planned Behavior (TPB) (Ajzen 1991; Fishbein and Ajzen 2010), which "refers to the individual's capacity to control the outcome of the behavior, in the sense of being technically capable of delivering the behavior and/or capturing the benefits of the outcome" (Delaroche 2020, pp. 3-4). In line with the TPB, we focus on the perceptions of farmers (rather than the elusive actual control they have), as in most cases, the opportunities and limits to action as they are perceived by the actor matter most for behavioral outcomes. In addition to TPB, the present study builds upon the conceptual approaches of constrained choice (Baur 2020; Hendrickson and James 2005; Stuart and Schewe 2016) and cross-level and cross-scale pressures (Feola et al. 2015), which draws attention to linkages between the spatial micro-, meso- and macro-level and short- and long-term effects. We combined these approaches with a stylized conceptualization of the behavioral change process in agriculture (see below) and drew upon the empirical literature on barriers to the adoption of sustainable agricultural practices. 
For understanding the barriers to sustainability transformations, the temporal dimension of farmer behavioral change deserves attention (Darnhofer 2020; Feola et al. 2015). Drawing on previous theories, we conceptualize farmer behavioral change as a 4-step process: (1) recognition of problem or opportunity, (2) identification of a suitable solution, (3) implementation, and (4) continued application of the new practice (Öhlmér et al. 1998; Sutherland et al. 2012). The concept of the action space only captures the opportunities for action regarding steps (2) to (4) of this cycle, i.e., the action space captures the constraints and opportunities that a farmer faces after she has developed a general intention to change (not yet, however, a specific intention for a particular course of action). The action space itself is dynamic: it may shift in response to policy changes, societal preference shifts, changing market structure, climatic changes, etc. This implies that policy interventions need to consider not only short-term behavioral changes but also their long-term stability.
Figure 1 illustrates the conceptual framework of farmers' action space, within the boundaries circumscribed by factors perceived by the farmer as beyond her immediate control (see typology of barriers below). The farmers' action space is influenced by the strength of barriers (orange arrows), which can interact in a synergistic or antagonistic way. Both farmers and non-farmer stakeholders have options to expand the action space of farmers (green and blue arrows, respectively).

\section{Factors influencing farmers' action space}

To identify leverage points for policy making, a deeper understanding of the factors shaping the action space is necessary. While a deterministic approach should be avoided, it is widely recognized that past and present external constraints limit farmers in their options (Baur 2020; Magrini et al. 2016; Sutherland et al. 2012). In the following, we present a typology of barriers beyond farmers' immediate control, based on literature on farmers' uptake of sustainable practices.

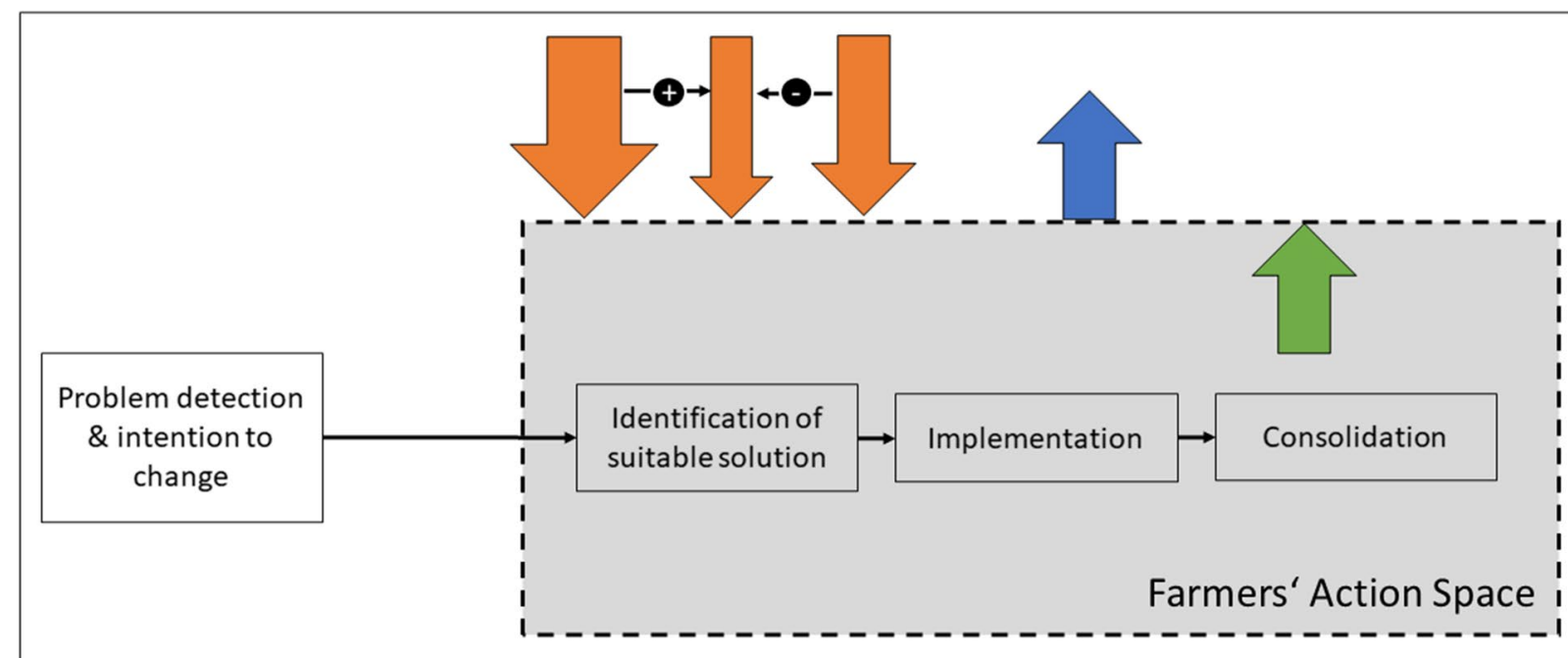

Factors beyond farmers' (perceived) immediate control

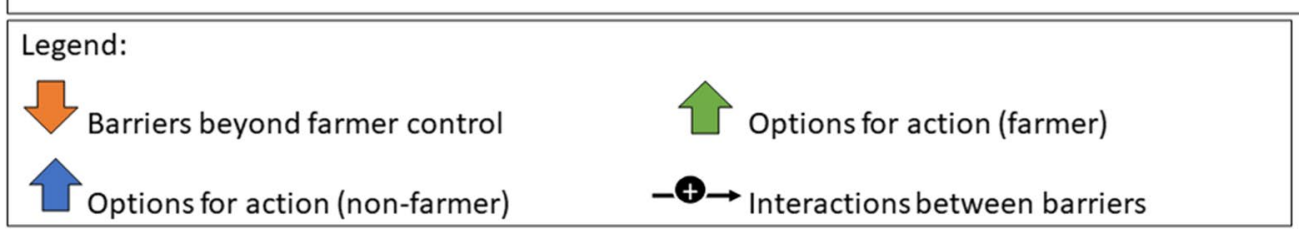

Fig. 1 Conceptual framework to analyze farmers' action space to implement sustainable farming practices. The solid line represents the factors beyond farmer's (perceived) immediate control. The dashed line indicates the size of farmers' action space, as is influenced by the strength of barriers beyond farmer control, which can interact in a synergistic or antagonistic way (orange arrows). Both farmers and non-farmer stakeholders have options to expand the action space of farmers (green and blue arrows, respectively) 


\section{Social barriers}

Farmers are affected in their decisions by multiple social factors, including the behavior of a diverse set of actors (e.g., neighbors, friends and relatives, agricultural advisors, local authorities, and businesses). These influence what farmers perceive as feasible, the expectations towards them, the signaling effects linked to a certain action, as well as prevailing norms of good agricultural practice and farmers' social identities (Dessart et al. 2019; Feola et al. 2015).

\section{Economic barriers}

Economic considerations linked to markets and state interventions (e.g., subsidization) are crucial in determining farmers' uptake of sustainable practices (Bartkowski and Bartke 2018). Relevant factors include production costs, product prices, and market access (Baur 2020). Uneven distribution of market power can limit farmers' opportunities for behavioral change (Baur 2020; Feola et al. 2015; Kipling et al. 2019). In addition, implementation costs, including additional investments, opportunity costs, and risk, influence the uptake of measures (Brown et al. 2021; Feliciano et al. 2014), while profitability does not ensure measure adoption (Feliciano et al. 2014; Mills et al. 2020). Several scholars discuss globalization and liberalization of agricultural trade as key forces driving the local conditions in which farmers operate (O'Brien and Leichenko 2000; Robinson 2018); a focus on international competitiveness has favored specialization and hindered the internalization of environmental costs of production (Oliver et al. 2018).

\section{Regulatory barriers}

Diverse public and private actors at local, national, and international levels create rules and standards which guide agricultural practices (Baur 2020; Feola et al. 2015). Farmers might be limited in their flexibility to adopt sustainable practices by rules from other areas ("siloed" policymaking; Baur 2020), as well as by contractual obligations (Stuart and Schewe, 2016). Despite their importance in facilitating the uptake of sustainability measures, subsidy schemes often fail to provide sufficient incentives and are sometimes even counterproductive (Lin 2011; Mills et al. 2020; Oliver et al. 2018; Sánchez et al. 2016), particularly when they are incoherent (Pe'er et al. 2019). Regulations can also increase the cost of implementation of sustainable agriculture, for example, through high transaction costs in terms of administrative work (Mack et al. 2019). In some cases, regulations imposed in one area may even make the adoption of sustainable practices in another area legally impossible (e.g., a ban on glyphosate would likely exclude the application of no-till practices in most contexts).

\section{Knowledge and technology barriers}

The knowledge farmers can draw on influences their uptake of sustainable practices (Mills et al. 2019). Over the years, farmers' knowledge has become increasingly geared towards conventional practices, suppressing traditional knowledge on sustainable practices and possibly leading to misconceptions about their costs and benefits (Lin 2011; Oliver et al. 2018). Accordingly, access to knowledge that farmers perceive as reliable and relevant, for example, through advisory services and demonstration networks, is crucial for adoption (Baur 2020; Dessart et al. 2019; Mills et al. 2019; Sánchez et al. 2016), though informal knowledge exchange, increasingly facilitated by modern media, also plays an important role (Mills et al. 2019; Burton and Riley 2018). In addition, knowledge availability might represent a challenge, for example, due to the focus of research and development on a few crops and corresponding technologies and due to a mismatch of priorities between research, policy, and practice perspectives (Lin 2011; Magrini et al. 2016; Saathoff et al. 2013; Scown et al. 2019; Smith et al. 2007).

\section{Biophysical barriers}

Local biophysical conditions, particularly the fit between a particular measure and local climate and soil conditions, affect farmers' decisions for or against its implementation (Bechini et al. 2015; Bijttebier et al. 2018; Feliciano et al. 2014; Mills et al. 2020). More generally, the local biophysical conditions, alongside socio-economic factors, have a major impact on farmers' decisions on the farming system (Silva et al. 2020). Due to the high heterogeneity of landscapes, the sustainability of agricultural practices is highly context-dependent. With global environmental change and most prominently climate change, the decisive conditions are rapidly changing, with possibly negative effects on the practical applicability and potential benefits of sustainable practices.

\section{Path dependencies at individual and systemic levels}

Another important phenomenon hindering a transformation towards sustainable agriculture is discussed under the term food system lock-in (Magrini et al. 2016; Oliver et al. 2018), a form of "undesirable resilience" (Dornelles et al. 2020). This describes a situation in which farmers and other actors along the food value chain are bound to certain behaviors by an environment geared towards these behaviors through technological complementarities, market structures, or social and cultural factors (Oliver et al. 2018). In addition, farmers might be limited in their choices due to their own past decisions through the so-called path dependencies. In some cases, a situation of lock-in arises, in which alternative 
options are "not [...] actively considered," despite possible advantages in comparison to current behavior (Sutherland et al. 2012, p. 145; see also Cumming et al. 2014). In this sense, path dependencies and lock-ins can be characterized as "solidified" sets of barriers and constraints.

\section{Interactions between barriers}

As suggested by the concept of "double exposure" (O'Brien and Leichenko 2000), the multiple barriers to sustainable agriculture do not always operate independently. In extreme cases, this may result in path dependencies and lock-ins (see above). The conceptual framework therefore includes two types of interactions, namely, alleviation and reinforcement, which can act either one-way or two-way. The recognition of these interactions is in line with the social-ecological systems (SES) approach, which has been widely used to analyze agriculture as both socially and ecologically embedded (Ostrom 2009; Oteros-Rozas et al. 2019). Thus, farmers work in a complex environment in which social and ecological factors interact at multiple levels (Feola and Binder 2010). These factors, as well as the interactions between them, may change over time, which emphasizes the need to consider the dynamic nature of farmers' action space (Darnhofer 2020; Feola et al. 2015).

\section{Options for action}

With options for actions, the framework refers to the possibilities of farmers and other stakeholders to widen the action space. Multiple actor types, including policy makers, businesses at all stages of the food value chain, consumers, and farmers themselves, can take actions to reduce the barriers beyond farmers' current and direct control. While the framework pictures an individual famer's action space, actions to widen the action space may include farmer collective actions as well as joint efforts across stakeholder groups. When analyzing these options, power asymmetries between these actor types should not be disregarded (Feola et al. 2015).

\section{Methods}

We applied the conceptual framework described above to investigate the action space of farmers in the German federal state of Saxony with respect to applying diversified crop rotations. We chose Saxony as it has rather low levels of adoption of sustainable practices and is dominated by intensive, large-scale farming (Dietze et al. 2019) and to fit in a larger research context where we investigate the role of farm management practices in the area. A two-step approach was employed to identify the barriers to diversified crop rotations that are relevant for the study area and, subsequently, weight them. This approach allows to focus on the experience of respondents, avoids biases arising from a mismatch between practitioners' and researchers' assessment of the situation, and thus improves the practical relevance of the findings (Niles et al. 2016; Bechini et al. 2020; Kopytko and Pruneddu 2018).

\section{Identification of barriers}

We conducted 10 qualitative, semi-structured interviews between April and June 2020, covering farming organizations and other stakeholders related to arable farming in Saxony, which were selected to represent a broad range of interests and involvement in processes of farmer behavioral change towards sustainable agriculture. Interviewees included three chairmen of sub-regional farmers' associations, who were also conventional farmers (I1, I6, I7); one organic farmer who was member of an alternative farmers' association (Arbeitsgemeinschaft bäuerliche Landwirtschaft) (I8); one representative of the Saxon farmer's association (federal state level) (I4); one representative of an organic farmers' association (I9); one employee of the Saxon State Office for Environment, Agriculture and Geology (I3); one non-governmental organization (NGO) (Naturschutzbund Deutschland, NABU) (2 simultaneous respondents) (I10); and two agricultural consultants, one of which was also a representative of a regional farmers association (I2, I5).

The interviews were conducted partly in person and partly online, lasted 45-90 min and were recorded with permission of the interviewee, transcribed, and coded using NVivo 12 Plus (QSR International Pty Ltd. 2018). Inductive category building was applied in coding to identify the most important barriers to the implementation of diversified crop rotations and the interactions between those barriers, allowing categories "to emerge out of the data" (Bryman 2016, p. 285). Based on the interviews, we selected 11 barriers that fulfilled the criteria of being (1) presented by the interviewees as separate issues and (2) encompassing, as failing to include an important barrier could strongly distort the weighting results.

\section{Weighting of the barriers}

We conducted an online survey between August and September 2020 to elicit the weights of the identified barriers in daily farmers' agricultural practices (see Electronic Supplementary Material (SM)). We used the database Grüne Berufe (green professions-a data base aimed to attract apprentices to farming-related professions) of the Saxon Ministry for Energy, Climate Protection, Environment and Agriculture (SMEKUL) as a starting point for contacting farmers (SMEKUL 2020). All farming businesses in the database for which e-mail addresses were 
available were contacted directly (in total 356 businesses, of which 4 had previously participated in the interviews), and additional contacts were made through snowball sampling. A total of 51 respondents fully completed all weighting questions in the online survey and were used for the analyses. Given that this study draws on convenience sampling, we acknowledge the limited generalizability of the findings (Bryman, 2016). Large farms were clearly overrepresented (see SM Table 2), which might be explained by their higher likelihood to take on apprentices and by higher time availability for office tasks.

We used a combination of rating and budget allocation to calculate relative weights of factors following Comín et al. (2018). For rating, we asked respondents to assign a level of importance to each factor, using a 1-10 scale. We then set the average rating of each barrier in relation to the sum of all average ratings. For budget allocation, respondents allocated an overall amount of points to the same list of items. The two results were averaged and rescaled to a 1-10 scale, yielding the final relative weight (see SM for formula).

\section{Results}

Our results clearly show that economic barriers were the most important barriers to diversified crop rotations (Fig. 2, Table 1). These were followed by legal factors, with low regulatory predictability having a slightly higher weight than strict regulations and bureaucratic workload. The two farmlevel barriers concerning resource availability and compatibility with the business strategy were both placed in the less important half of barriers and were seen as only half as impactful as the highest-ranking barrier price pressure. The barriers linked to availability of and access to the necessary knowledge were perceived as least important. Overall, the respondents felt rather strongly limited in their action space (German "Handlungsspielraum"), as indicated by an average rating of 6.25 out of 10 on that question (see SM). This coincides with the average rating of 6.27 assigned to the individual barriers, which allows us to assume that the selected barriers covered the most important factors limiting farmers' perceived leeway to implement climate-friendly crop rotation and thus providing evidence for the internal validity of results. At the same time, relative weight of barriers that resulted from the survey in some cases strongly diverged from the importance assigned to the barrier in the

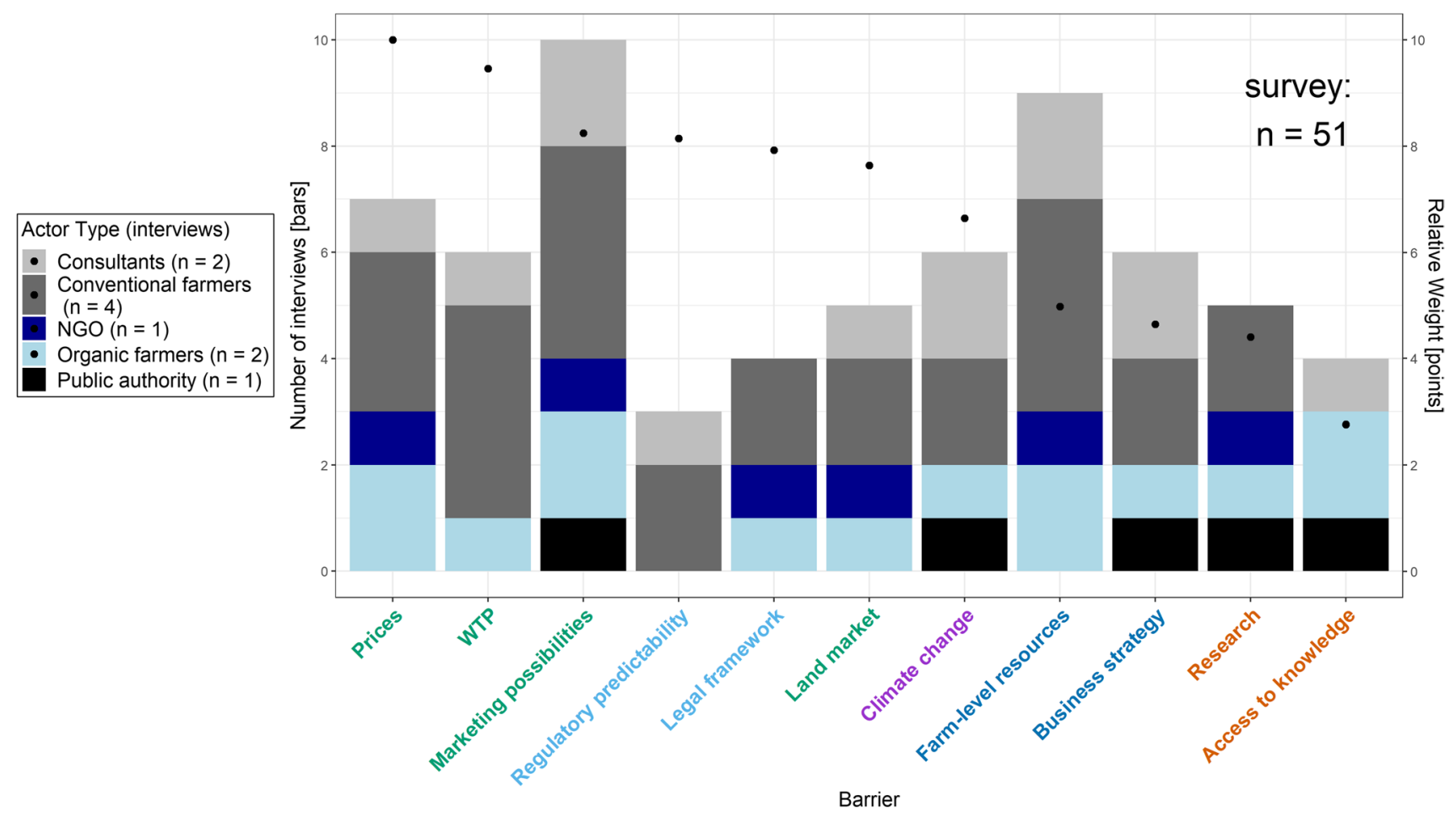

Fig. 2 Overview of interview and survey results, showing the number of interviews mentioning each of the 11 selected barriers by actor type [stacked bars] and the relative weight assigned in the survey [points]. Label colors indicate barrier category: economic (green), regulatory (light blue), biophysical (purple), path dependencies (dark blue), and knowledge and technology (red). See Table 1 for details on relative weight 
Table 1 Rank and relative weight assigned to each barrier through the survey, by barrier type

\begin{tabular}{|c|c|c|c|}
\hline Barrier type & Barrier (as named in the survey) & $\begin{array}{l}\text { Rank } \\
\text { (out of } \\
11 \text { ) }\end{array}$ & Relative Weight \\
\hline \multirow[t]{4}{*}{ Economic } & $\begin{array}{l}\text { Prices (low prices for the corresponding crops, price pressure from competitors and } \\
\text { downstream sectors) }\end{array}$ & 1 & 10.00 \\
\hline & $\begin{array}{l}\text { WTP (limited willingness to pay for climate-friendly products, limited awareness for } \\
\text { agriculture) }\end{array}$ & 2 & 9.47 \\
\hline & $\begin{array}{l}\text { Marketing possibilities (limited using and/or marketing possibilities, lack of processing } \\
\text { industry) }\end{array}$ & 3 & 8.26 \\
\hline & Land market (rising land prices, declining land availability) & 6 & 7.66 \\
\hline \multirow[t]{2}{*}{ Regulatory } & Regulatory predictability (lack of regulatory predictability) & 4 & 8.16 \\
\hline & Legal framework (strict legal environment, time-consuming bureaucracy) & 5 & 7.95 \\
\hline Biophysical & Climate change (climate change, especially dryness and mild winters) & 7 & 6.67 \\
\hline \multirow[t]{2}{*}{ Path dependencies } & $\begin{array}{l}\text { Farm-level resources (lack of resources within the business: time, knowledge, technol- } \\
\text { ogy, money) }\end{array}$ & 8 & 5.02 \\
\hline & $\begin{array}{l}\text { Business strategy (limited compatibility of the measures with the business strategy or } \\
\text { structure) }\end{array}$ & 9 & 4.70 \\
\hline \multirow[t]{2}{*}{ Knowledge and technology } & Research (scientific knowledge is lacking or not practically applicable) & 10 & 4.46 \\
\hline & Access to knowledge (restricted access of farmers to the necessary knowledge) & 11 & 2.82 \\
\hline
\end{tabular}

Table 2 Main points associated with each barrier type as identified through the interviews

\section{Economic barriers}

- Financial viability of diverse crop rotations is low due to price pressure caused by low willingness to pay, power asymmetries, and international competition

- Difficult financial situation of businesses forces farmers to prioritize economic over environmental considerations

- Lack of regional processing and distribution infrastructure further limits farmers in their choices

- Rising land prices put additional pressure on other production costs

\section{Biophysical barriers}

- Climate change is hindering legume and cover crop cultivation in various regions of Saxony

- Adaptation of crop choice as a response to climate change is limited to the few marketable crops

- Climate change induced yield losses in previous years restrict the financial leeway to implement environmentally friendly practices

\section{Regulatory barriers}

- Quickly changing regulations contrast with long amortization times of associated investments and a need for long-term planning

- Environmental regulation is linked to high transaction and implementation costs

- Regulations are restrictive and practically not applicable

- Policy incoherence challenges the implementation of diversified crop rotations

Path dependencies

- On-farm technology and knowledge might bind farms to certain practices

- Continued consequences of GDR collectivization practices are evident in large fields without structural elements

Knowledge barriers

- Lack of knowledge for implementation was perceived as a problem by stakeholders other than farmers interviews, pointing to a mismatch in perceptions between farmers and non-farmer stakeholders.

\section{Economic barriers}

Both interviews and the survey portrayed the economic operating environment as the most important set of constraints of their action space to implement diversified crop rotations. The three barriers concerned with agricultural markets and value chains were most prominent (i.e., largest relative weight; Table 1). Interviewees agreed that in conventional farming, currently only a few crops are economically viable, causing Saxon arable farming to be dominated by wheat, barley, rape seed, and maize (I2, I5, I6, I7, I9, I10). Interviewees and survey respondents proposed multiple, interlinked explanations for the limited economic viability of diversified crop rotations.

One key problem associated with diversified farming systems was that additional costs were not met by additional revenue. Several respondents stated that the proposed practices increase their production costs (I6, I9, similarly I8). At the same time, no premium prices for sustainable products 
were expected, representing additional pressure on already small profit margins. In addition, prices fluctuate (I4), which conflicts with planning crop rotations for several years (compare I3). Low producer prices, combined with climate change effects, have complicated farmers' financial situation in recent years (I1, I9, compare I4, I7). Consequently, many farming businesses lack the financial leeway to prioritize environmental over economic considerations.

Price pressure was explained with consumers' limited willingness to pay for environmentally friendly products and the position of Saxon farmers within global agricultural markets and value chains characterized by power asymmetries. Five out of six interviewed farmers and farmers' association representatives mentioned the lack of willingness to pay for climate-friendly products as a barrier to the implementation of diversified crop rotations (I1, I4, I6, I7, I9). Several interviewees pointed to a perceived attitude-behavior gap in consumers (I1, I4, I7). For Saxon agriculture to become more sustainable, some interviewees demanded a shift of preferences towards regional products and less meat-based diets (I6, I7, I8).

Other value chain actors and the global markets were also attributed responsibility for low producer prices. In a globalized market for agricultural goods, prices do not reflect heterogeneity in agricultural practices, nor in local cost structures and externalities (I6, I7, I8). The "unleashed" [entfesselt] (I8) agricultural markets were linked to a problematic policy environment, including free trade agreements (I7, I8, similarly I9). Low prices were furthermore explained by the market power of retailers, including globally operating companies (I6, I7, I9). Agricultural production in Germany was portrayed as atomized, with individual businesses having little power in relation to the highly concentrated processing and retailing sectors (I2, I10).

Most respondents pointed to a lack of marketing possibilities for crops that would need to be added to the crop rotation (I1, I3, I4, I6, I7, I10), for which there is no direct use on-farm. Several interviewees emphasized that farmers were limited in their crop choice by the demands of the processing industry, retailers, and, ultimately, by society (I1, I4, I6, I7, SR10). In addition, a lack of local processing industry and, more generally, underdeveloped regional food systems were deemed problematic, as regional processing and storage infrastructure are necessary to keep transaction costs low and ensure feasibility of a certain crop (I2, I5, I7, I8). Furthermore, several respondents criticized that deficient local infrastructure results in long transport distances with high climate impact (I2, I5, I8, I9, SR51).

Uneven distribution of livestock within Germany and low prices for imported soy as feed were seen as barriers to using cover crops and locally produced legumes for feed (I6, I8, similarly I10). This hints at the more general problem that the potential economic benefits of sustainable practices are not realized in conventional farming due to externalized environmental costs of less sustainable alternatives (I5, I8, I9, SR54). In Saxony specifically, a decrease in the processing industry was observed, possibly linked to the structural transitions following German reunification (I7, I8, I9, SR51).

Rising land prices (I2, ID74), combined with a tendency towards higher percentages of leased in comparison to owned land (I2), represent a major cost factor and exert pressure on farmers to keep other costs low (I1). Interviewees pointed to a gradual withdrawal of agricultural land for other land uses (I7, I10) and were worried that agricultural land could be subject to speculation or used for tax avoidance (I1, I7, I8). In addition, one agricultural consultant was concerned about capitalization of CAP direct payments, meaning that these are transferred to land prices and lead to short-term tenure contracts, as landowners hope for increased subsidies (I2, similarly SR64).

Interviewees and survey respondents drew multiple connections between the issues discussed above, suggesting that they cannot be understood as separable problems but rather as different parts of a self-reinforcing system which hinders a sustainability transformation of agriculture. One important mechanism in this context was the interconnection between limited demand for environmentally friendly food and the increasingly complex and globalized food system: the growing disconnect between producer and consumer through longer, globalized value chains (I1, I2, I4, I7) was associated with limited consumer awareness, which in turn was associated with high price pressure on farmers. The lack of premium prices for regional and/or environmentally friendly products further adds to this. As part of this process of globalization, regional food systems have gradually eroded, rendering a diversification of crop rotations more difficult (I8, I9, SR31, SR51). In addition, the economic operating environment was seen as the main cause of limited financial leeway of farming businesses, which caused a strong prioritization of economic over environmental considerations and left farmers with little options to invest in, for example, the development of regional processing and marketing options. Several interviewees and survey respondents expressed the belief that higher willingness to pay by consumers and higher producer prices would increase willingness and actual implementation of environmentally friendly practices (I7, I9, SR51).

The interview and survey results allow to identify some potential heterogeneity in the level and nature of the effects on different farmers, although the sample size does not allow for robust statements about within-sample heterogeneity. Firstly, the mode of production seems important, with the described barriers being more relevant to conventional than to organic farmers. Organic products achieve higher prices and enjoy demand for more diverse products, while diversity in the cropping system is facilitated by organic production 
standards. Additionally, direct marketing was associated with capturing more of the final value of the product and with being linked to more conscious consumers. The location of a business influenced options to establish novel forms of direct marketing such as community-supported agriculture (I7) as well as the distance to processing industry and on-farm use options. The latter, in addition to local soil and climate conditions, was also affected by the branches of production, with mixed arable and livestock farms having more usage possibilities, for example, for forage plants. However, these businesses were also less flexible, as much of their capital was tied in immobile technology such as buildings for livestock. Lastly, businesses with higher shares of rented land might be more affected by rising land prices.

\section{Regulatory barriers}

Two constraints of farmers' action space were linked to the regulatory frameworks governing agriculture in Germany. Key points of criticism were a perceived lack of regulatory predictability, overly prescriptive and impractical regulations, as well as high transaction costs.

The relevant regulations were perceived as unstable, which conflicted with a need for planning security as a precondition to adapt the farming system to certain sustainability standards and to invest in corresponding technology with possibly long amortization times (I5, I7). According to one interviewee, the framework was changing so quickly that "you have to adapt even before it's there if you want to master it successfully" (I1). The regulatory environment was criticized for high associated transaction and implementation costs. In addition, the complex system of regulations and related bureaucratic work were described as causing stress and anxiety to farmers (I2, I10). An often-cited example was the time-consuming and rapidly changing bureaucratic load linked to CAP subsidies (I2, I8, I10). In this context, smaller businesses were perceived at a disadvantage because they cannot afford specialized staff for administrative work. This was considered relevant to diversified crop rotations as more diverse rotations may require dividing fields into smaller parcels, leading to additional bureaucratic workload as subsidies are granted on a field-by-field basis (I10).

The implementation of diversified crop rotations is, according to interviewees, further restricted by laws aiming to regulate other environmental problems. Several interviewees perceived parts of the relevant regulations as not adapted to practical agriculture and/or ineffective (I1, I7, I8). The main regulation under criticism was the amended fertilization ordinance (Düngeverordnung 2017/2020; I1, I7, I8, SR57). Criticism included short and inflexible time spans for relevant activities and a lack of differentiation between nitrogen sources, e.g., between synthetic and organic fertilizers (I8). More generally, agri-environmental regulations were portrayed as overly prescriptive (I8, SR13, SR51). Some interviewees saw the use of synthetic fertilizers and pesticides as a precondition for diversified crop rotations, and stated that legume and cover crop cultivation was hindered by regulations on pesticide use (I1, I5, I6, I7). At the same time, it was pointed out that political targets to reduce pesticide use were not specific enough to guide implementation (I3).

\section{Biophysical barriers}

The main barrier to diversified crop rotations that was associated with climate change is water scarcity, which has already affected the range of crops that can be grown in certain locations (I6). Several of the most grown crops in Saxony, including rape seed, wheat, barley, maize, potatoes, sunflowers, and turnips, are being negatively affected by climate change (I1, I3, I7). As water scarcity induced by climate change especially affects the spring season, spring sowing generally has become more difficult (I2, I6). Crops sown in fall, in contrast, benefit from winter humidity (I2, I6). The need to adapt crop choice to changing climate conditions coincides with a market environment that limits crop choice (see 4.1), causing the shift to happen within the range of dominant species (I6, I3). Crops that could make rotations more sustainable are not among the winners of climate change: legumes formerly suitable for the region, such as peas and broad beans, were described as very sensitive to dry conditions (I9). Dry soils complicate the establishment of cover crops (I3, I4, I5), which results in the risks of losing the investments in seeds (I5) and of having a bare fallow (I4). In addition, cover crops compete with the following cash crop for soil moisture (I4, I5). Mild winters further complicate cover crop cultivation as common cultivation practices assume that they die from frost (I4). In short, the technical solutions needed to deal with new climatic conditions were often missing due to lack of research on the new conditions (I9).

Climate change exacerbates the impact of several other barriers: interviewees repeatedly referred to yield losses in previous years as a reason why businesses lacked money for environmental protection (I1, I2, I6). Additionally, climate change was linked to new technology and knowledge needs, which may increase production costs (I6, I7, I8, I9). In turn, climate change also had negative effects of farmers' intention to implement mitigation measures, because of a narrative of the farmer as the victim rather than the culprit of climate change (I3).

\section{Path dependencies}

The available financial, technological, and human resources largely determine the way a business can respond to the 
multiple factors that affect the action space and are thus a crucial determinant of the businesses' capability to overcome the barriers to diversified crop rotations. Generally, the further away the business is from sustainability-oriented thinking and practices, the higher are the costs to reach them. For example, previous production decisions were described as determining technology needs linked to diversified crop rotations (I4, I7, I9) and developing new production branches was considered costly (I5, I6). In addition to a technological path dependency, respondents described a knowledge-based path dependency, as a farmer's knowledge was said to focus on the main past activities (I3, I5, I9, I10). In addition, workforce availability is considered a problem in Saxony (I2, I4, SR65). Current employees and managers are often not fully prepared to implement sustainability measures due to a lack of time and training as well as short-term employment (I2, I4, I5, I8, I10). In cooperatives, which are an important form of farmer cooperation in Germany, accountability of managers to members might create a status-quo bias (I5), in a situation where crop choice decisions are made short-term and mainly based on market prices (I3). This contrasts with diversified crop rotations, which need to be planned beforehand.

Business-level path dependencies are accompanied by structural issues in Saxony: regarding land allocation and structure, the German Democratic Republic (GDR) is showing long-term consequences, as farming was collectivized in so-called LPG (Landwirtschaftliche Produktionsgenossenschaften; agricultural production associations), landscape elements were removed and fields combined, incentivizing large-scale production of a few crops rather than diverse crop rotations (I8, also see I10). However, it should be noted that similar processes of simplification also took place in Western Germany.

\section{Knowledge factors}

Despite high importance assigned to knowledge barriers by several interview partners, restricted availability of and access to knowledge were weighted low in the survey. As the interviews covered a more diverse group of stakeholders than the survey, this divergence might be explained by differences in self- and outside perception of conventional farmers' knowledge levels and access to knowledge.

Interviewees from several stakeholder groups identified a need for more research on climate-friendly agriculture (I3, I9, I10), especially on organic agriculture (I10). One farmer claimed that the scientific community fails to propose practically applicable solutions (I6) while another stated that "most of the time, the practicing farmer is already one step ahead of what climate scientists propose" (I1). In contrast, other interviewees claimed that there was already plenty of knowledge awaiting implementation (I9, I10). The public authority representative shared that, because of unavailable knowledge, the authority did not know which practices to incentivize (I3).

In addition to knowledge production, knowledge distribution was considered a problem. Agricultural vocational training was criticized for a focus on economic issues, while underemphasizing ecology, sustainability, and organic agriculture (I8, I9). As agricultural best practices are highly context-specific, acquiring the necessary knowledge requires experimentation or specialized advisory services and demonstration farms (I1,I2, I3, I4, I9, I10), which is costly for producers, especially in the Saxon context where advisory services are largely privatized (I3). Experiments and increased investment in advisory services by public authorities partly alleviated this problem (I3, I4).

Knowledge barriers were linked to several other barriers. For example, the lack of knowledge diminishes the response capacity of farmers facing climate change (I9, I6) and the development of novel forms of using more diverse crops (I3). Furthermore, difficulties to quantify soil fertility and thus the effects of specific measures on it were cited as impeding efforts to convince farmers of the on-farm benefits of adopting diversified crop rotations (I3). Regarding access to knowledge, incomplete agricultural education and costly advisory services increase implementation costs which might be problematic given limited financial leeway. Table 2 provides a summary of the main findings for each barrier type.

\section{Discussion}

Human agents (such as farmers) are constrained in their actions by numerous barriers. The action space perspective adopted in this paper emphasizes these barriers and how they circumscribe what an agent can feasibly be expected to do, given her own perceptions. In that sense, the action space perspective can provide information about what farmers cannot do (e.g., why they cannot adopt sustainable practices). Still, a number of further behavioral factors operate within the action space and ultimately determine whether the farmer will adopt a practice if her action space allows for it (Delaroche 2020; Dessart et al. 2019). Therefore, understanding the action space is necessary but not sufficient to understand and predict the adoption of sustainable practices by farmers. Still, external barriers to adoption are often overlooked by policy; their targeted alleviation and removal can be an efficient agri-environmental policy approach. In the following, we discuss the implications for policy and research that emerge from our study of Saxon farmers' action space. We organize the discussion along three hierarchical policy levels (regional, national, and international), which 
we complement by a discussion of more general implications and limitations of our work.

\section{Implications at regional level}

At the regional level (i.e., federal state level in Germany), where the practical implementation of many agricultural policies takes place, we found that the main barriers constraining farmers' action space were the bureaucratic load, knowledge deficits, and lack of advisory services to support both issues.

Our interviews and survey corroborate previous findings suggesting that farmers in Germany and elsewhere in Europe perceive the bureaucratic load associated with the reception of agricultural payments as high (Bartkowski and Bartke 2018). In this context, Mack et al. (2019) demonstrate that clear communication of documentation and reporting requirements and their rationale by authorities seems to play an important role in reducing the perceived bureaucratic load. This immediately suggests an avenue for policy intervention, as the number and extent of administrative tasks (and thus, transaction costs) faced by modern farmers is significant. Here, there is increasing hope and attempts to improve the situation through digitalization (see Weersink et al. 2018; Ehlers et al. 2021). However, many challenges remain (Klerkx et al. 2019; Ehlers et al. 2021), including legal issues (e.g., data ownership), economic issues (e.g., investment in technologies), and infrastructure issues (e.g., internet availability in rural areas). Another option is to reduce the workload elsewhere, for instance, with decision support tools (Pahmeyer et al. 2021) or digitized agri-environmental scheme designs (Bartkowski et al. 2021).

Our study reveals an interesting contrast between the assessment of the role of knowledge deficits between farmers and non-farmer stakeholders. This aligns with the anecdotal evidence suggesting that environmental concerns are not well reflected in agricultural education (Joormann and Schmidt 2017) while recognizing the large role of informal and experiential knowledge (Šūmane et al. 2018) and farmers' networks of knowledge exchange (Albizua et al. 2020; Mills et al. 2019; Burton and Riley 2018). Also, advisory services have been repeatedly identified as an important factor in this and similar contexts (e.g., Ingram and Mills 2019; Wuepper et al. 2021), as was strengthening the presence of environmental topics in agricultural education curricula (Joormann and Schmidt 2017). Despite the low weight of knowledge barriers in our survey, there are many potential levers to be used by policy and other actors involved in communicating practical agri-environmental knowledge. This is especially true given we could not assess whether it is other stakeholders underestimating farmers' knowledge or farmers overestimating it.

\section{Implications at national level}

At the national level, the low prices of agricultural products, lack of policy coherence and land prices are the major issues. Low willingness to pay and power asymmetries in food value chains-both key reasons behind low producer prices-are complex issues and exhibit multiple links to other topics raised in the interviews. The market power of retailers and processing industries, compared to the low power of individual farmers, has been well documented in the economic literature (e.g., Sexton and Xia 2018; Bonanno et al. 2018). Strengthening farmer cooperation has been raised as a remediation strategy (Candemir et al. 2021), possibly linked to governance interventions such as collaborative agri-environmental payment schemes (Westerink et al. 2017). Although farmers unions and other types of organization might have a larger chance to change barriers beyond the farm level, these collective action problems fall out of the scope of this paper. Another widely discussed yet understudied option is direct marketing, which also may influence consumers' willingness to pay for sustainably produced food by bringing them closer to the production realities (Opitz et al. 2017; 2019).

Some scholars speak, in line with our interviewees, of a vote-buy gap (Paul et al. 2019), where people voice their willingness to purchase more expensive, but sustainably produced food, while their purchases contradict this. However, as argued by Bartkowski and Baum (2019) in the context of genome-edited food, the issue may be more complex than this, including factors such as social dilemmas and information asymmetries that are only limitedly addressed by labelling. These tensions and complexities suggest that a policy focus on agricultural production only is too narrow and that there is a need to consider agrifood systems in their entirety (as attempted e.g., in the EU Farm-to-Fork Strategy) (see De Schutter et al. 2020; Oteros-Rozas et al. 2019).

In this context, policy coherence is crucial-as bemoaned by the interviewees as well as in the scientific literature (Pe'er et al. 2019), agricultural and agri-environmental policies in the EU are often incoherent, both with respect to their objectives and the instruments they adopt. This situation is potentially aggravated by the stepwise implementation of the European Green Deal, which seems at odds with the planned reform of the CAP (Pe'er et al. 2020; Scown et al. 2020). Also, it adds to the perceived unpredictability of policy development. However, from the point of view of regulators, there is a trade-off between predictability and adaptability of policies (Gawel and Lehmann 2019). Given that those regulated cannot anticipate future changes in policy adapting policies to new information, while sensible from the point of view of regulators and societal welfare, may deter beneficial investments by those regulated. 
The precise role of tenure and land prices as a barrier to the adoption of sustainable practices, raised by our interviewees and in the survey, is unclear. For instance, recent evidence suggests that the effect of land tenure on land management is highly contextual and may be negligible if tenure contracts are long-term (Leonhardt et al. 2019; Daedlow et al. 2018). Also, the extent of the capitalization of CAP direct payments in land prices is ambiguous (Graubner 2018). Some evidence is available of pressures increasing demand for land for non-agricultural purposes exert on rural areas (Bunkus and Theesfeld 2018). However, the evidence base seems currently too narrow to allow for the formulation of policy recommendations, such as a more strict regulation of agricultural land markets.

\section{Implications at international level}

The topics raised in our interviews also demonstrate the importance of international policy frameworks, particularly in the domains of trade and climate. For instance, the already mentioned market power of retailers is further aggravated by their ability to procure agricultural products in global markets, which can be considered a consequence of the rules of the World Trade Organization (WTO). While the globalization of agricultural markets is associated with many benefits for consumers (Qaim 2017), in its current form, the international trade regime often leads to a "race-to-the-bottom" in terms of environmental standards as countries seek to ensure international competitiveness (Oliver et al. 2018; see also Fuchs et al. 2020).

The other international policy area of high importance is climate policy. As indicated by the discussion on the potential of cover crops as well as the limited financial flexibility in and around drought years, climate change is a central barrier to Saxon farmers' action space in adopting sustainable management practices. Given agriculture's contribution to climate change (Clark et al. 2020), this constitutes a positive feedback loop. Policymaking needs to consider the interactions between enhancing farming system resilience and adopting sustainable practices (Meuwissen et al. 2019; Oliver et al. 2018; Rosa-Schleich et al. 2019; Wiréhn et al. 2020).

\section{General implications}

Two general policy-relevant implications arise from our study: the interdependency and dynamism of the barriers. First, as stressed above repeatedly, many barriers are interlinked; isolated changes to one barrier can thus lead to unintended shifts in other barriers. Both trade-offs and synergies are possible, so that a holistic perspective is required for effective policy interventions. Note, for instance, the finding from the interviews that while mixed farms are more flexible due to their higher business diversity, they also face higher fixed costs of investments associated with livestock farming, which limits their financial flexibility. Similarly, investments in digital technologies may reduce bureaucratic load, but at the same time, they imply financial pressures that may tighten the action space elsewhere.

Second, special emphasis should be put on the notion that the action space is dynamic, as it responds, often in non-obvious ways, to changes in the social, economic, institutional, and natural environments that ultimately determine both the "actual" barriers faced by farmers and their perceptions of their action space. Accordingly, attempts to broaden the action space by means of policy interventions, e.g., aiming at increasing the adoption of sustainable management practices, need to consider not only the action space as it is when the intervention is introduced but also anticipate likely future developments that may affect the action space (e.g., climate change, international trade agreements, etc.). For policy interventions to be effective, they need to affect the action space in a durable manner, which makes it crucial to identify actors with highest potential for durable change (see Marselle et al. 2020).

\section{Limitations of the study}

Our results exhibit a high internal validity regarding the choice of barriers for the survey (i.e., similar results for the overall limitation of the action space and for the average of the strengths assigned to all barriers) despite the fact that our definition of diversified crop rotations included several practices which might be subject to different barriers and the relatively small sample size $(N=51)$. The main downside of the small sample size is our inability to provide any robust insights into the potential heterogeneity of action space perceptions (e.g., differences between old and young farmers or between organic and conventional farms). While the broad definition of diversified crop rotations limits the applicability of results to each single practice relevant in this context (e.g., cover crops, perennial crops), this broad approach allowed capturing general perceptions of farmers regarding their action space, leaving open the context-specific relevance of individual practices. As in any case study based on a mixedmethod approach, we recommend interpreting our results with care for two reasons. Firstly, interviews captured the barriers to interviewee's own understanding of what we framed as climate-friendly crop rotations, while the survey pre-defined the corresponding practices, which could have caused a mismatch in definitions in some cases. Secondly, the framing of diversified crop rotations as climate-friendly crop rotations in the surveys is likely to have influenced the responses we captured, although the practices and thus the barriers are likely the same even if the main goal of diversification is not climate mitigation. 


\section{Conclusions}

This study operationalizes and applies the concept of farmers' action space to adopt sustainable management practices, in order to separate decision-making factors within the sphere of influence of farmers from those that lie beyond farmers' immediate control. We identified the most important factors limiting farmers' perceived leeway to implement diversified crop rotations. Our mixed-method empirical application demonstrates that arable farmers in the German federal state of Saxony perceive having a rather small action space to implement diversified crop rotations as a climate mitigation strategy. A key reason for this is that diversified crop rotations require the cultivation of a variety of crops that are not economically viable under current conditions. In many cases, deviating from the most profitable practices and engaging in environmentally friendly alternatives is not perceived as possible, because of very limited financial leeway (low margins) and a perceived immediate threat to the survival of the business. The action space represents a useful conceptual linkage element between the behavior of individual farmers and broader phenomena such as the global agricultural market, climate change, or agri-environmental policy. While the action space perspective is not sufficient to explain what farmers will do (as this also requires knowledge of individual motivations, guided by values, norms, attitudes and other behavioral factors), it can illuminate why they do not engage in particular behaviors. Such a perspective can contribute to mediating the tensions between individual farmers' concerns and the broader need for environmentally friendly agriculture. A focus on the multiple factors beyond the perceived immediate control of farmers is essential, given an increased recognition of the need to understand sustainable agriculture within the context of global food systems (Caron et al. 2018). Our results suggest that especially the economic and regulatory operating environment of farmers limits their capability to respond to the strong political and societal demands for sustainable agriculture. Addressing this mismatch might be challenging, as the global food system is characterized by path dependencies and the barriers pertaining to the market environment are mutually reinforcing and seem to constitute an instance of "undesirable resilience" (Oliver et al. 2018). Still, this study provides a rationale for policymaking that aims at creating an enabling market and regulatory environment for sustainable agriculture, including consideration of the role of other actors in the food value chain (e.g., retailers and consumers). The creation of such an enabling environment implies a comprehensive transformation that needs to encompass all stages of the food value chain and consider the synergies and trade-offs between different aspects of sustainability (Caron et al. 2018; Oliver et al. 2018).
Supplementary Information The online version contains supplementary material available at https://doi.org/10.1007/s10113-021-01848-1.

Funding Open Access funding enabled and organized by Projekt DEAL.

Open Access This article is licensed under a Creative Commons Attribution 4.0 International License, which permits use, sharing, adaptation, distribution and reproduction in any medium or format, as long as you give appropriate credit to the original author(s) and the source, provide a link to the Creative Commons licence, and indicate if changes were made. The images or other third party material in this article are included in the article's Creative Commons licence, unless indicated otherwise in a credit line to the material. If material is not included in the article's Creative Commons licence and your intended use is not permitted by statutory regulation or exceeds the permitted use, you will need to obtain permission directly from the copyright holder. To view a copy of this licence, visit http://creativecommons.org/licenses/by/4.0/.

\section{References}

Ajzen I (1991) The theory of planned behavior. Organ Behav Hum Decis Process 50:179-211. https://doi.org/10.15288/jsad.2011. 72.322

Albizua A, Bennett E, Pascual U, Larocque G (2020) The role of the social network structure on the spread of intensive agriculture: an example from Navarre. Spain Reg Environ Change 20:99. https:// doi.org/10.1007/s10113-020-01676-9

Alignier A, Solé-Senan XO, Robleño I, Baraibar B, Fahrig L et al (2020) Configurational crop heterogeneity increases within-field plant diversity. J Appl Ecol 57(4):654-663. https://doi.org/10. 1111/1365-2664.13585

Bartkowski B, Bartke S (2018) Leverage Points for Governing Agricultural Soils: A Review of Empirical Studies of European Farmers' Decision-Making. Sustainability 10:3179. https://doi.org/10.3390/ su10093179

Bartkowski B, Baum CM (2019) Dealing with rejection: An application of the exit-voice framework to genome-edited food. Front Bioeng Biotechnol 7:57. https://doi.org/10.3389/fbioe.2019.00057

Bartkowski B, Droste N, Ließ M, Sidemo-Holm W, Weller U, Brady MV (2021) Payments by modelled results: A novel design for agri-environmental schemes. Land Use Policy 102:105230. https://doi.org/10.1016/j.landusepol.2020.105230

Baur P (2020) When farmers are pulled in too many directions: comparing institutional drivers of food safety and environmental sustainability in California agriculture. Agric Hum Values 37(4):1175-1194. https://doi.org/10.1007/s10460-020-10123-8

Bechini L, Costamagna C, Zavattaro L, Grignani C, Bijttebier J, Ruysschaert G (2020) Drivers and barriers to adopt best management practices. Survey among Italian dairy farmers. J Clean Prod 245:118825. https://doi.org/10.1016/j.jclepro.2019.118825

Bechini L, Costamagna C, Zavattaro L, Grignani C, Bijttebier J, Ruysschaert G (2015) Barriers and drivers towards the incorporation of crop residue in the soil. Analysis of Italian farmers' opinion with the theory of planned behaviour. Italian Journal of Agronomy 10(4) 178-10.4081/ija.2015.663

Bijttebier J, Ruysschaert G, Hijbeek R, Werner M, Pronk AA et al (2018) Adoption of non-inversion tillage across Europe: Use of a behavioural approach in understanding decision making of farmers. Land Use Policy 78:460-471. https://doi.org/10.1016/j.landu sepol.2018.05.044 
BMEL (2019) Ackerbaustrategie 2035: Perspektiven für einen produktiven und vielfältigen Pflanzenbau. Bundesministerium für Ernährung und Landwirtschaft, Berlin

Bonanno A, Russo C, Menapace L (2018) Market power and bargaining in agrifood markets: A review of emerging topics and tools. Agribusiness 34:6-23. https://doi.org/10.1002/agr.21542

Braito M, Leonhardt H, Penker M, Schauppenlehner-Kloyber E, Thaler G, Flint CG (2020) The plurality of farmers' views on soil management calls for a policy mix. Land Use Policy 99:104876. https://doi.org/10.1016/j.landusepol.2020.104876

Brown C, Kovács E, Herzon I, Villamayor-Tomas S, Albizua A et al (2021) Simplistic understandings of farmer motivations could undermine the environmental potential of the Common Agricultural Policy. Land Use Policy 101:105136. https://doi.org/10. 1016/j.landusepol.2020.105136

Bryman A (2016) Social Research Methods. Oxford, UK: Oxford University Press

Bunkus R, Theesfeld I (2018) Land Grabbing in Europe? Socio-Cultural Externalities of Large-Scale Land Acquisitions in East Germany. Land 7:98. https://doi.org/10.3390/land7030098

Burton RJF, Riley M (2018) Traditional Ecological Knowledge from the internet? The case of hay meadows in Europe. Land Use Policy 70:334-346. https://doi.org/10.1016/j.landusepol.2017. 10.014

Campbell BM, Beare DJ, Bennett EM, Hall-Spencer JM, Ingram JSI et al (2017) Agriculture production as a major driver of the Earth system exceeding planetary boundaries. Ecol Soc 22(4):8. https://doi.org/10.5751/ES-09595-220408

Caron P, Ferrero y de Loma-Osorio, G., Nabarro, D., Hainzelin, E., Guillou, et al (2018) Food systems for sustainable development: proposals for a profound four-part transformation. Agron Sustain Dev 38(4):41. https://doi.org/10.1007/s13593-018-0519-1

Clark MA, Domingo NGG, Colgan K, Thakrar SK, Tilman D et al (2020) Global food system emissions could preclude achieving the $1.5^{\circ}$ and $2^{\circ} \mathrm{C}$ climate change targets. Science $370: 705-708$. https://doi.org/10.1126/science.aba7357

Comín FA, Miranda B, Sorando R, Felipe-Lucia MR, Jiménez JJ, Navarro E (2018) Prioritizing sites for ecological restoration based on ecosystem services. J Appl Ecol 55(3):1155-1163. https://doi.org/10.1111/1365-2664.13061

Daedlow K, Lemke N, Helming K (2018) Arable Land Tenancy and Soil Quality in Germany: Contesting Theory with Empirics. Sustainability 10:2880. https://doi.org/10.3390/su10082880

Darnhofer I (2020) Farming from a Process-Relational Perspective: Making Openings for Change Visible. Sociol Rural 60(2):505528. https://doi.org/10.1111/soru.12294

De Schutter O, Jacobs N, Clément C (2020) A 'Common Food Policy' for Europe: How governance reforms can spark a shift to healthy diets and sustainable food systems. Food Policy 96:101849. https://doi.org/10.1016/j.foodpol.2020.101849

Delaroche M (2020) Adoption of conservation practices: what have we learned from two decades of social-psychological approaches? Curr Opin Environ Sustain 45:25-35. https://doi. org/10.1016/j.cosust.2020.08.004

Demenois J, Torquebiau E, Arnoult MH, Eglin T, Masse D et al (2020) Barriers and Strategies to Boost Soil Carbon Sequestration in Agriculture. Front Sustain Food Syst 4:37. https://doi. org/10.3389/fsufs.2020.00037

Dessart FJ, Barreiro-Hurlé J, van Bavel R (2019) Behavioural factors affecting the adoption of sustainable farming practices: a policyoriented review. Eur Rev Agric Econ 46:417-471. https://doi. org/10.1093/erae/jbz019

Dietze V, Hagemann N, Jürges N, Bartke S, Fürst C (2019) Farmers consideration of soil ecosystem services in agricultural management - A case study from Saxony, Germany. Land Use Policy 81:813-824. https://doi.org/10.1016/j.landusepol.2018.11.003
Dornelles AZ, Boyd E, Nunes RJ, Asquith M, Boonstra WJ et al (2020) Towards a bridging concept for undesirable resilience in social-ecological systems. Global Sustainability 3:e20. https:// doi.org/10.1017/sus.2020.15

Düngeverordnung vom 26. Mai 2017 (BGB1. I S. 1305), die durch Artikel 1 der Verordnung vom 28. April 2020 (BGBl. I S. 846) geändert worden ist (DüV). [Fertilization ordinance of May 26th, 2017 (BGB1. I S. 1305), as amended by Article 1 of the ordinance of April 28th, 2020 (BGBl. I S. 846).

Eder A, Salhofer K, Scheichel E (2021) Land tenure, soil conservation, and farm performance: An eco-efficiency analysis of Austrian crop farms. Ecol Econ 180:106861. https://doi.org/10. 1016/j.ecolecon.2020.106861

Ehlers M-H, Huber R, Finger R (2021) Agricultural policy in the era of digitalisation. Food Policy 100:102019. https://doi.org/ 10.1016/j.foodpol.2020.102019

European Commission. (2018) Agriculture and Climate Mitigation. CAP Specific Objectives Explained, Brief 4.

Feliciano D, Hunter C, Slee B, Smith P (2014) Climate change mitigation options in the rural land use sector: Stakeholders' perspectives on barriers, enablers and the role of policy in North East Scotland. Environ Sci Policy 44:26-38. https://doi.org/10.1016/j. envsci.2014.07.010

Feola G, Binder CR (2010) Towards an improved understanding of farmers' behaviour: The integrative agent-centred (IAC) framework. Ecol Econ 69(12):2323-2333. https://doi.org/10.1016/j. ecolecon.2010.07.023

Feola G, Lerner AM, Jain M, Joseph M, Montefrio F, Nicholas KA (2015) Researching farmer behaviour in climate change adaptation and sustainable agriculture : Lessons learned from five case studies. J Rural Stud 39:74-84. https://doi.org/10.1016/j.jrurstud. 2015.03.009

Fishbein, M., Ajzen, I. (2010) Predicting and Changing Behavior: The Reasoned Action Approach. New York: Psychology Press.

Fuchs Richard, Brown Calum, Rounsevell Mark (2020) Europe's Green Deal offshores environmental damage to other nations. Nature 586(7831):671-673. https://doi.org/10.1038/d41586-020-02991-1

Gawel E, Lehmann P (2019) Should renewable energy policy be 'renewable'? Oxf Rev Econ Policy 35:218-243. https://doi.org/ 10.1093/oxrep/grz002

Graubner M (2018) Lost in space? The effect of direct payments on land rental prices. Eur Rev Agric Econ 45:143-171. https://doi. org/10.1093/erae/jbx027

Hass AL, Kormann UG, Tscharntke T, Clough Y, Baillod AB et al (2018) Landscape configurational heterogeneity by small-scale agriculture, not crop diversity, maintains pollinators and plant reproduction in western Europe. Proceedings of the Royal Society b: Biological Sciences 285(1872):20172242. https://doi.org/ 10.1098/rspb.2017.2242

Hatt S, Boeraeve F, Artru S, Dufrêne M, Francis F (2018) Spatial diversification of agroecosystems to enhance biological control and other regulating services: An agroecological perspective. Sci Total Environ 621:600-611. https://doi.org/10.1016/j.scitotenv. 2017.11.296

Hendrickson MK, James HS (2005) The ethics of constrained choice: How the industrialization of agriculture impacts farming and farmer behavior. J Agric Environ Ethics 18(3):269-291. https:// doi.org/10.1007/s10806-005-0631-5

Heißenhuber, A., Haber, W., Krämer, C. (2015) 30 Jahre SRU-Sondergutachten "Umweltprobleme der Landwirtschaft"-eine Bilanz. Dessau-Roßlau: Umweltbundesamt.

Ingram J, Mills J (2019) Are advisory services "fit for purpose" to support sustainable soil management? An assessment of advice in Europe. Soil Use Manag 35:21-31. https://doi.org/10.1111/ sum. 12452 
IPCC (2019) Climate Change and Land: an IPCC special report on climate change, desertification, land degradation, sustainable land management, food security, and greenhouse gas fluxes in terrestrial ecosystems. Summary for Policymakers. Genf: IPCC.

Joormann, I., Schmidt, T. (2017) Hindernisse und Perspektiven für mehr Biodiversität in der Agrarlandschaft: F.R.A.N.Z.-Studie (Thünen Working Paper 75). Thünen-Institut, Braunschweig.

Kipling RP, Taft HE, Chadwick DR, Styles D, Moorby J (2019) Challenges to implementing greenhouse gas mitigation measures in livestock agriculture: A conceptual framework for policymakers. Environ Sci Policy 92:107-115. https://doi.org/10.1016/j.envsci. 2018.11.013

Klerkx, L., Jakku, E., Labarthe, P. (2019) A review of social science on digital agriculture, smart farming and agriculture 4.0: New contributions and a future research agenda. NJAS - Wagening. J. Life Sci. 90-91:100315. doi:https://doi.org/10.1016/j.njas.2019. 100315

KLU (2019) Landwirtschaft quo vadis? Agrar- und Ernährungssysteme der Zukunft - Vielfalt gewähren, Handlungsrahmen abstecken / Position der Kommission Landwirtschaft beim Umweltbundesamt (KLU). Dessau-Roßlau: Umweltbundesamt.

Knierim A, Labarthe P, Laurent C, Prager K, Kania J et al (2017) Pluralism of agricultural advisory service providers - Facts and insights from Europe. J Rural Stud 55:45-58. https://doi.org/10. 1016/j.jrurstud.2017.07.018

Kopytko N, Pruneddu A (2018) Triple-win strategy? Why is not everyone doing it? A participant-driven research method to reveal barriers to crop rotation in Ukraine. Clim Change 149(2):189-204. https://doi.org/10.1007/s10584-018-2229-8

Lamine C, Darnhofer I, Marsden TK (2019) What enables just sustainability transitions in agrifood systems? An exploration of conceptual approaches using international comparative case studies. J Rural Stud 68:144-146. https://doi.org/10.1016/j.jrurstud.2019. 03.010

Leonhardt H, Braito M, Penker M (2021) Why do farmers care about rented land? Investigating the context of farmland tenure. J Soil Water Conserv 76:89-102. https://doi.org/10.2489/jswc.2021. 00191

Leonhardt H, Penker M, Salhofer K (2019) Do farmers care about rented land? A multi-method study on land tenure and soil conservation. Land Use Policy 82:228-239. https://doi.org/10.1016/j. landusepol.2018.12.006

Lin BB (2011) Resilience in agriculture through crop diversification: Adaptive management for environmental change. Bioscience 61(3):183-193. https://doi.org/10.1525/bio.2011.61.3.4

Mack G, Kohler A, Heitkämper K, El-Benni N (2019) Determinants of the perceived administrative transaction costs caused by the uptake of an agri-environmental program. J Environ Plan Manag 62:1802-1819. https://doi.org/10.1080/09640568.2018.1515311

Magrini MB, Anton M, Cholez C, Corre-Hellou G, Duc G et al (2016) Why are grain-legumes rarely present in cropping systems despite their environmental and nutritional benefits? Analyzing lock-in in the French agrifood system. Ecol Econ 126:152-162. https://doi. org/10.1016/j.ecolecon.2016.03.024

Marselle MR, Turbe A, Shwartz A, Bonn A, Colléony A (2020) Addressing behavior in pollinator conservation policies to combat the implementation gap. Conserv Biol 35(2):610-622. https://doi. org/10.1111/cobi.13581

Meuwissen MPM, Feindt PH, Spiegel A, Termeer CJAM, Mathijs E et al (2019) A framework to assess the resilience of farming systems. Agric Syst 176:102656. https://doi.org/10.1016/j.agsy. 2019.102656

Mills J, Ingram J, Dibari C, Merante P, Karaczun Z et al (2020) Barriers to and opportunities for the uptake of soil carbon management practices in European sustainable agricultural production.
Agroecol Sustain Food Syst 44(9):1185-1211. https://doi.org/10. 1080/21683565.2019.1680476

Mills J, Reed M, Skaalsveen K, Ingram J (2019) The use of Twitter for knowledge exchange on sustainable soil management. Soil Use Manag 35:195-203. https://doi.org/10.1111/sum.12485

Moerkerken A, Blasch J, van Beukering P, van Well E (2020) A new approach to explain farmers' adoption of climate change mitigation measures. Clim Change 159(1):141-161. https://doi.org/10. 1007/s10584-019-02595-3

Nardo, M., Saisana, M., Tarantola, A., Stefano, S. (2005) Tools for Composite Indicators Building.

Niles MT, Brown M, Dynes R (2016) Farmer's intended and actual adoption of climate change mitigation and adaptation strategies. Clim Change 135(2):277-295. https://doi.org/10.1007/ s10584-015-1558-0

O'Brien K, Leichenko R (2000) Double exposure: assessing the impacts of climate change within the context of economic globalization. Glob Environ Chang 10:221-232. https://doi.org/10. 1021/acs.est.7b05861

Öhlmér B, Olson K, Brehmer B (1998) Understanding farmers' decision making processes and improving managerial assistance. Agric Econ 18(3):273-290. https://doi.org/10.1016/S01695150(97)00052-2

Oliver TH, Boyd E, Balcombe K, Benton TG, Bullock JM et al (2018) Overcoming undesirable resilience in the global food system. Glob Sustain 1:e9. https://doi.org/10.1017/sus.2018.9

Opitz I, Specht K, Piorr A, Siebert R, Zasada I (2017) Effects of consumer-producer interactions in alternative food networks on consumers' learning about food and agriculture. Morav Geogr Rep 25:181-191. https://doi.org/10.1515/mgr-2017-0016

Opitz I, Zoll F, Zasada I, Doernberg A, Siebert R, Piorr A (2019) Consumer-producer interactions in community-supported agriculture and their relevance for economic stability of the farm - An empirical study using an Analytic Hierarchy Process. J Rural Stud 68:22-32. https://doi.org/10.1016/j.jrurstud.2019.03.011

Ostrom E (2009) A general framework for analyzing sustainability of social-ecological systems. Science 325(5939):419-422. https:// doi.org/10.1126/science.1172133

Oteros-Rozas E, Ruiz-Almeida A, Aguado M, González JA, RiveraFerre MG (2019) A social-ecological analysis of the global agrifood system. Proc Natl Acad Sci 116(52):26465-26473. https:// doi.org/10.1073/pnas.1912710116

Pahmeyer C, Kuhn T, Britz W (2021) 'Fruchtfolge': A crop rotation decision support system for optimizing cropping choices with big data and spatially explicit modeling. Comput Electron Agric 181:105948. https://doi.org/10.1016/j.compag.2020.105948

Paul AS, Lusk JL, Norwood FB, Tonsor GT (2019) An experiment on the vote-buy gap with application to cage-free eggs. J Behav Exp Econ 79:102-109. https://doi.org/10.1016/j.socec.2019.02.005

Pe'er G, Bonn A, Bruelheide H, Dieker P, Eisenhauer N et al (2020) Action needed for the EU Common Agricultural Policy to address sustainability challenges. People Nat. 2:305-316. https://doi.org/ 10.1002/pan3.10080

Pe'er G, Zinngrebe Y, Moreira F, Sirami C, Schindler S et al (2019) A greener path for the EU Common Agricultural Policy. Science 365:449-451. https://doi.org/10.1126/science.aax3146

Qaim M (2017) Globalisation of agrifood systems and sustainable nutrition. Proc Nutr Soc 76:12-21. https://doi.org/10.1017/S0029 665116000598

QSR International Pty Ltd. (2018) NVivo (Version 12), https://www. qsrinternational.com/nvivo-qualitative-data-analysis-software/ home. Accessed 8 Oct 2021

Robinson GM (2018) Globalization of agriculture. Ann Rev Resour Economics 10:133-160. https://doi.org/10.1146/annurev-resou rce-100517-023303 
Rosa-Schleich J, Loos J, Mußhoff O, Tscharntke T (2019) Ecologicaleconomic trade-offs of Diversified Farming Systems - A review. Ecol Econ 160:251-263. https://doi.org/10.1016/j.ecolecon.2019. 03.002

Saathoff W, von Haaren C, Dechow R, Lovett A (2013) Farm-level assessment of $\mathrm{CO} 2$ and $\mathrm{N} 2 \mathrm{O}$ emissions in Lower Saxony and comparison of implementation potentials for mitigation measures in Germany and England. Reg Environ Change 13(4):825-841. https://doi.org/10.1007/s10113-012-0364-8

Sánchez B, Álvaro-Fuentes J, Cunningham R, Iglesias A (2016) Towards mitigation of greenhouse gases by small changes in farming practices: understanding local barriers in Spain. Mitig Adapt Strat Glob Change 21(7):995-1028. https://doi.org/10. 1007/s11027-014-9562-7

Scown MW, Winkler KJ, Nicholas KA (2019) Aligning research with policy and practice for sustainable agricultural land systems in Europe. Proc Natl Acad Sci 116(11):4911-4916. https://doi.org/ 10.1073/pnas. 1812100116

Scown MW, Brady MV, Nicholas KA (2020) Billions in misspent EU agricultural subsidies could support the Sustainable Development Goals. One Earth 3(2):237-250. https://doi.org/10.1016/j.oneear. 2020.07.011

Sexton RJ, Xia T (2018) Increasing Concentration in the Agricultural Supply Chain: Implications for Market Power and Sector Performance. Annu Rev Resour Econ 10:229-251. https://doi.org/10. 1146/annurev-resource-100517-023312

Silva JF, Santos JL, Ribeiro PF, Canadas MJ, Novais A et al (2020) Identifying and explaining the farming system composition of agricultural landscapes: The role of socioeconomic drivers under strong biophysical gradients. Landsc Urban Plan 202:103879. https://doi.org/10.1016/j.landurbplan.2020.103879

SMEKUL (2020) Grüne Berufe - Ausbildungsbetriebe in Sachsen im Bereich Land- und Ernährungswirtschaft. Retrieved October 4, 2020, from https://www.gruene-berufe.sachsen.de/ausbildung sbetriebe/Landwirt_in.html

Smith P, Martino D, Cai Z, Gwary D, Janzen H et al (2007) Policy and technological constraints to implementation of greenhouse gas mitigation options in agriculture. Agr Ecosyst Environ 118(14):6-28. https://doi.org/10.1016/j.agee.2006.06.006

Soule MJ, Tegene A, Wiebe KD (2000) Land Tenure and the Adoption of Conservation Practices. Am J Agric Econ 82:993-1005

Stuart D, Schewe RL (2016) Constrained Choice and Climate Change Mitigation in US Agriculture: Structural Barriers to a Climate Change Ethic. J Agric Environ Ethics 29(3):369-385. https://doi. org/10.1007/s10806-016-9605-z
Šūmane S, Kunda I, Knickel K, Strauss A, Tisenkopfs T et al (2018) Local and farmers' knowledge matters! How integrating informal and formal knowledge enhances sustainable and resilient agriculture. J Rural Stud 59:232-241. https://doi.org/10.1016/j.jrurstud. 2017.01.020

Sutherland LA, Burton RJF, Ingram J, Blackstock K, Slee B, Gotts N (2012) Triggering change: Towards a conceptualisation of major change processes in farm decision-making. J Environ Manage 104:142-151. https://doi.org/10.1016/j.jenvman.2012.03.013

Umweltbundesamt. (2020). Summary table on emission trends for Germany since 1990, all GHGs in kt CO2. Retrieved from https:// www.umweltbundesamt.de/daten/klima/treibhausgas-emissionenin-deutschland\#minderungsziele-fur-treibhausgase. Accessed 8 Oct 2021

UNEP (2016) Food Systems and Natural Resources. A Report of the Working Group on Food Systems of the International Resource Panel.

Weersink A, Fraser E, Pannell D, Duncan E, Rotz S (2018) Opportunities and Challenges for Big Data in Agricultural and Environmental Analysis. Annu Rev Resour Econ 10:19-37. https://doi.org/10. 1146/annurev-resource-100516-053654

Westerink J, Jongeneel R, Polman N, Prager K, Franks J et al (2017) Collaborative governance arrangements to deliver spatially coordinated agri-environmental management. Land Use Policy 69:176-192. https://doi.org/10.1016/j.landusepol.2017.09.002

Wiesmeier M, Mayer S, Burmeister J, Hübner R, Kögel-Knabner I (2020) Feasibility of the 4 per 1000 initiative in Bavaria : A reality check of agricultural soil management and carbon sequestration scenarios. Geoderma 369(2020):114333. https://doi.org/10. 1016/j.geoderma.2020.114333

Wiréhn L, Käyhkö J, Neset TS, Juhola S (2020) Analysing trade-offs in adaptation decision-making-agricultural management under climate change in Finland and Sweden. Reg Environ Change 20(18):1-14. https://doi.org/10.1007/s10113-020-01585-x

Wuepper D, Roleff N, Finger R (2021) Does it matter who advises farmers? Pest management choices with public and private extension. Food Policy 99:101995. https://doi.org/10.1016/j.foodpol. 2020.101995

Publisher's note Springer Nature remains neutral with regard to jurisdictional claims in published maps and institutional affiliations. 